\title{
Measurements of atmospheric aerosol vertical distributions above Svalbard, Norway, using unmanned aerial systems (UAS)
}

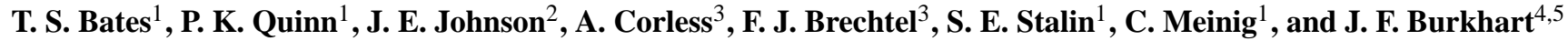 \\ ${ }^{1}$ NOAA/PMEL, Seattle, WA, USA \\ ${ }^{2}$ JISAO, University of Washington, Seattle, WA, USA \\ ${ }^{3}$ Brechtel Mfg. Inc., Hayward, CA, USA \\ ${ }^{4}$ NILU, Norwegian Institute for Air Research, Kjeller, Norway \\ ${ }^{5} \mathrm{UCM}$, University of California, Merced, CA, USA
}

Correspondence to: T. S. Bates (tim.bates@noaa.gov)

Received: 8 February 2013 - Published in Atmos. Meas. Tech. Discuss.: 11 March 2013

Revised: 27 June 2013 - Accepted: 19 July 2013 - Published: 26 August 2013

\begin{abstract}
Atmospheric aerosol vertical distributions were measured above Svalbard, Norway, in April 2011 during the Cooperative Investigation of Climate-Cryosphere Interactions campaign (CICCI). Measurements were made of the particle number concentration and the aerosol light absorption coefficient at three wavelengths. A filter sample was collected on each flight at the altitude of maximum particle number concentration. The filters were analyzed for major anions and cations. The aerosol payload was flown in a NOAA/PMEL MANTA Unmanned Aerial System (UAS). A total of 18 flights were flown during the campaign totaling 38 flight hours. The data show frequent aerosol layers aloft with high particle number concentration $\left(1000 \mathrm{~cm}^{-3}\right)$ and enhanced aerosol light absorption $\left(1 \mathrm{Mm}^{-1}\right)$. Air mass histories of these aerosol layers were assessed using FLEXPART particle dispersion modeling. The data contribute to an assessment of sources of BC to the Arctic and potential climate impacts.
\end{abstract}

\section{Introduction}

The potential role of black carbon (BC) in climate change in the Arctic has gained considerable attention. In particular, numerous model-based studies have indicated there may be a link between observed rapid climate warming and $\mathrm{BC}$ that is transported from lower latitudes and deposited in the Arctic (Jacobson, 2010; Shindell, 2007; Shindell and Faluvegi, 2009; Shindell et al., 2008; Flanner, 2009; Flanner et al., 2007, 2009; Hansen et al., 2005; Hansen and Nazarenko, 2004). However, in situ measurements of aerosol absorption, a proxy for $\mathrm{BC}$, at several monitoring sites in the Arctic have revealed a decreasing trend over the past 15 to $30 \mathrm{yr}$ (Sharma et al., 2006; Quinn et al., 2007; Hirdman et al., 2010) implying that radiative forcing due to $\mathrm{BC}$ should also be decreasing. Similarly, ice core analysis (McConnell et al., 2007) shows a general decrease in mean winter BC concentrations over the last half-century. Repeat snow sample analyses indicate that $\mathrm{BC}$ concentrations in Arctic snow have not changed significantly between the 1980s and present (Doherty et al., 2010) To resolve these seemingly opposed trends of increasing Arctic temperatures and decreasing BC concentrations, the processes controlling black carbon transport, deposition and absorption-driven warming must be well understood and compared to other processes influencing Arctic warming.

A particularly important process in the Arctic surface energy budget is the snow/ice albedo feedback whereby temperature increases lead to melting of snow and ice, and exposure of underlying dark surfaces. The resulting decrease in surface albedo leads to further absorption of solar radiation and surface warming (Køltzow, 2007; UNEP, 2011). Several recent studies of pollutant transport to the Arctic indicate that the deposition of BC on snow/ice surfaces may enhance the snow/ice albedo feedback by increasing the darkening of the surface and the absorption of solar radiation and subsequent warming (Law and Stohl, 2007; Quinn et al., 2008). Currently, there are insufficient measurements to evaluate black carbon transport to the Arctic, the vertical distributions of BC 
over the Arctic, and the induced changes in surface albedo resulting from the deposition of $\mathrm{BC}$ to snow/ice surfaces. To date, all assessments of the impact of $\mathrm{BC}$ on surface albedo and temperature are model based.

The NOAA/PMEL Soot Transport, Absorption, and Deposition Study (STADS) was conducted in Ny-Ålesund, Svalbard, Norway between 7 April and 6 May 2011. Coordination of the various international groups took place through the Coordinated Investigation of Climate-Cryosphere Interactions (CICCI) initiative. The central goal of the initiative was to improve the understanding of processes controlling the distribution of black carbon (BC) in the Arctic atmosphere, the deposition of $\mathrm{BC}$ to snow and ice surfaces, and the resulting climate impacts. Measurements of the vertical distribution of $\mathrm{BC}$ in the atmosphere over $\mathrm{Ny}$-Ålesund using a new unmanned aerial system (UAS) equipped with an aerosol measurement package are described here. Measurements were made on Svalbard at the Holtadalfohna Plateau; Kongsfjord fast ice; and the sea ice north of Spitsbergen. Flight activities were conducted cooperatively between NOAA and the Northern Research Institute (NORUT) and coordinated in conjunction with the field based activities of the Norwegian Institute for Air Research (NILU) along with other members of the CICCI initiative.

\section{Methods}

The MANTA $\mathrm{C} 1$ is a category II medium duration, fixed wing, unmanned aircraft system (UAS) designed and built by Advanced Ceramics Research (ACR, now owned by BAE) (Fig. 1). The aircraft weighs $16.3 \mathrm{~kg}$ without payload and fuel ( $27.7 \mathrm{~kg}$ maximum takeoff weight). The wingspan is $2.7 \mathrm{~m}$, height $0.62 \mathrm{~m}$ and length $1.92 \mathrm{~m}$. The aircraft is powered by a $3.8 \mathrm{~kW}, 56 \mathrm{cc}, 2$-stroke/2-cylinder gasoline engine that powers a carbon 3-blade pusher propeller. Takeoff is accomplished with a catapult launcher or rolled takeoff. Landing is automated using DGPS and requires $<300 \mathrm{~m}$ of runway. The aircraft is capable of flight at a maximum service ceiling of $3660 \mathrm{~m}$ above mean sea level (a.m.s.l.), cruises at $26 \mathrm{~m} \mathrm{~s}^{-1}$ and has a total endurance of up to $4.5 \mathrm{~h}$ (takeoff to recovery) with a main and 2 wing fuel tanks $(8.1 \mathrm{~L}$ fuel). The typical climb rate during research flights is $1.25 \mathrm{~m} \mathrm{~s}^{-1}$. For data collection averaged over $60 \mathrm{~s}$ (e.g., aerosol light absorption, see below), the vertical resolution is $75 \mathrm{~m}$ and the horizontal resolution is $1560 \mathrm{~m}$. The aircraft is controlled with a Cloud Cap (Piccolo) autopilot that can navigate between up to 99 geographic waypoints and land the plane on a runway within a $1 \mathrm{~m}^{2}$ target box. The avionics allow for automatic loiter on command and execute lost-link procedures to reacquire communication if needed. The Integrated Ground Control Station (IGCS) provides command and control. During flight operations, communication with the MANTA is through an omnidirectional antenna using a $900 \mathrm{MHz}$ radio frequency (RF)

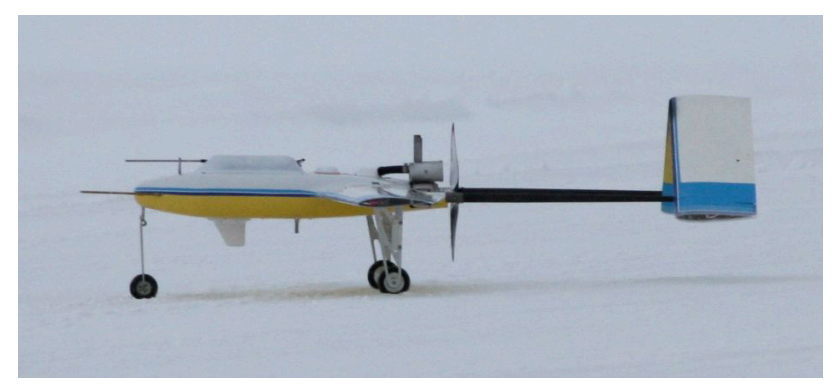

Fig. 1. Manta UAS on runway after first landing in Ny-Ålesund.

for primary communication. Beyond line of sight communication is through an Iridium SatCom link.

The UAS embedded payload computer was designed around the Motorola 68332 system and programmed in C. Although this 32-bit processor has the power to compute and multi-task simultaneous functions, it was built to be energy efficient to minimize battery usage during flights. The computer consists of $4 \mathrm{Mb}$ of flash memory, a 12-bit A/D converter with 8 input channels, two RS232 channels, a hardware watchdog, a real-time clock, and 512 bytes of RAM. The function of the payload computer is to implement and regulate all of the primary functions of the science payload. The embedded computer stores the high resolution data $(1 \mathrm{~Hz})$ from the payload and transmits a subset of data to the ground station via RF or Iridium modems. During the flight, the payload scientist has the ability to send commands to the computer to change the data download feed and control each payload instrument.

The UAS is equipped with a rugged temperature and relative humidity $(\mathrm{RH})$ probe designed by the Rotronic Instrument Corporation (model HC2). Temperatures can measured between -40 and $60^{\circ} \mathrm{C}$ with an accuracy of $\pm 0.1^{\circ} \mathrm{C}$. RH can be measured between 0 to $100 \%$ with an accuracy of $\pm 0.8 \%$. Data from the temperature and RH sensors are relayed in real-time to the IGCS so that flight plans can be amended to better target atmospheric layers and monitor for potential icing conditions. The real-time temperature and $\mathrm{RH}$ data are especially important in high latitude environments where ice on the pitot tube could quickly bring the plane down.

The aerosol measurement package, designed and built by Brechtel Manufacturing Inc. (BMI, Hayward, CA; ACCESS Model 9400, http://www.brechtel.com/ACCESS_brochure. pdf), is modular in design and can be quickly installed and removed from the MANTA payload bay (Fig. 2). The package is powered by one of two aircraft batteries $(15 \mathrm{Ah}, 12 \mathrm{~V}$ each) for the duration of the flight (up to $4.5 \mathrm{~h}$ ). The aerosol package includes a passively pumped isokinetic inlet to bring air and particles into the module. The instruments in the module, which sub-sample off of the main inlet, include a mixing condensation particle counter (MCPC, modified BMI Model 1710, $12.7 \mathrm{~cm}$ cube), a three-wavelength absorption photometer (BMI ABS, $12.7 \times 7.6 \times 7.6 \mathrm{~cm})$, and a 


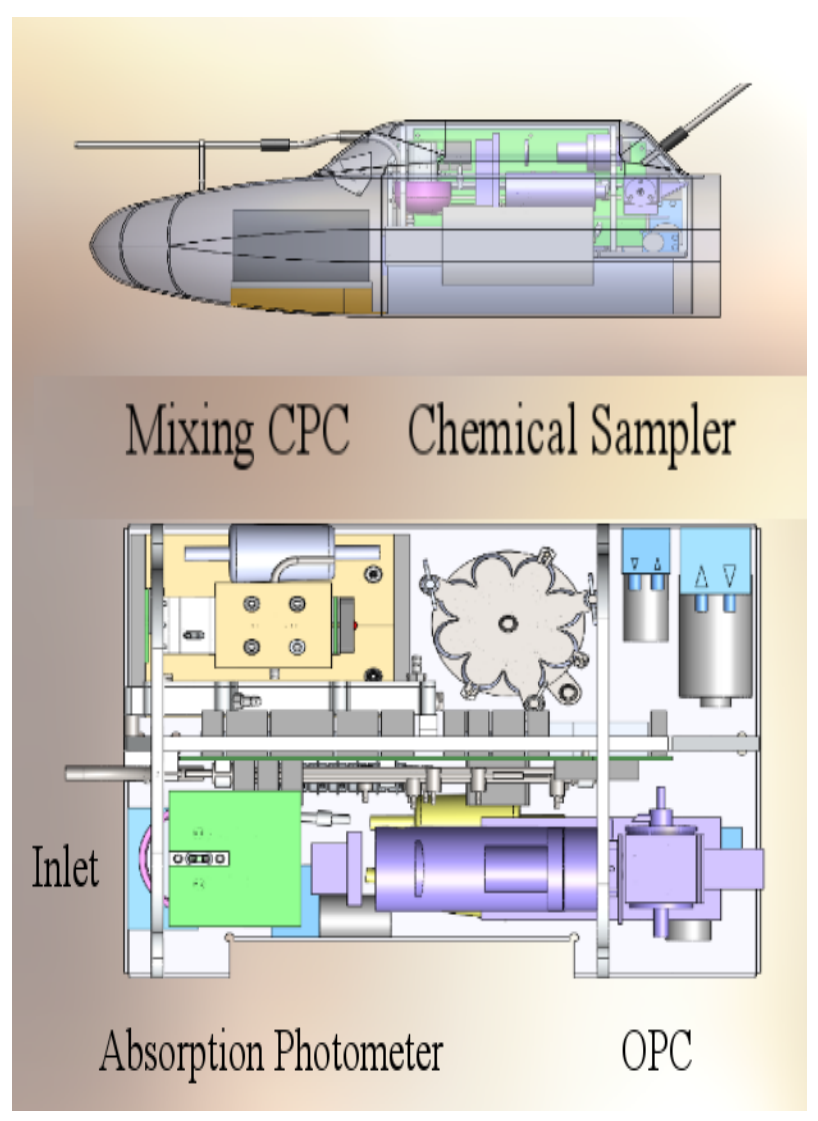

Fig. 2. Aerosol measurement package in the MANTA showing the inlet and exhaust lines, mixing condensation particle sampler (MCPC), 8-filter chemical sampler, and absorption photometer (ABS) flown during STADS. The optical particle counter was not available for the experiment.

Multi-Channel Chemical Filter Sampler. An optical particle counter is also under development for the package but was not ready for this field deployment.

The MCPC has a $180 \mathrm{~ms}$ response time, grows particles in a butanol-saturated flow, and counts particles in the 5 to $3000 \mathrm{~nm}$ diameter size range. Modifications to the butanol handling components of the commercial Model 1710 were implemented to address the high-vibration environment of the UAS. The MCPC concentration measurement was characterized by sampling size-selected $60 \mathrm{~nm}$ particles from a differential mobility analyzer. An electrometer sampled the same particles in parallel with the MCPC and provided a reference measurement of concentration over the range of 100 to 100000 particles $\mathrm{cm}^{-3}$. Agreement between the MCPC and the electrometer (Ioner Model 5030) was within $\pm 8 \%$ over the concentration range and was independent of concentration.

The ABS provides real-time measurements of the aerosol light absorption coefficient at 450,525 , and $624 \mathrm{~nm}$. The ABS transmits light from a LED source through a sample
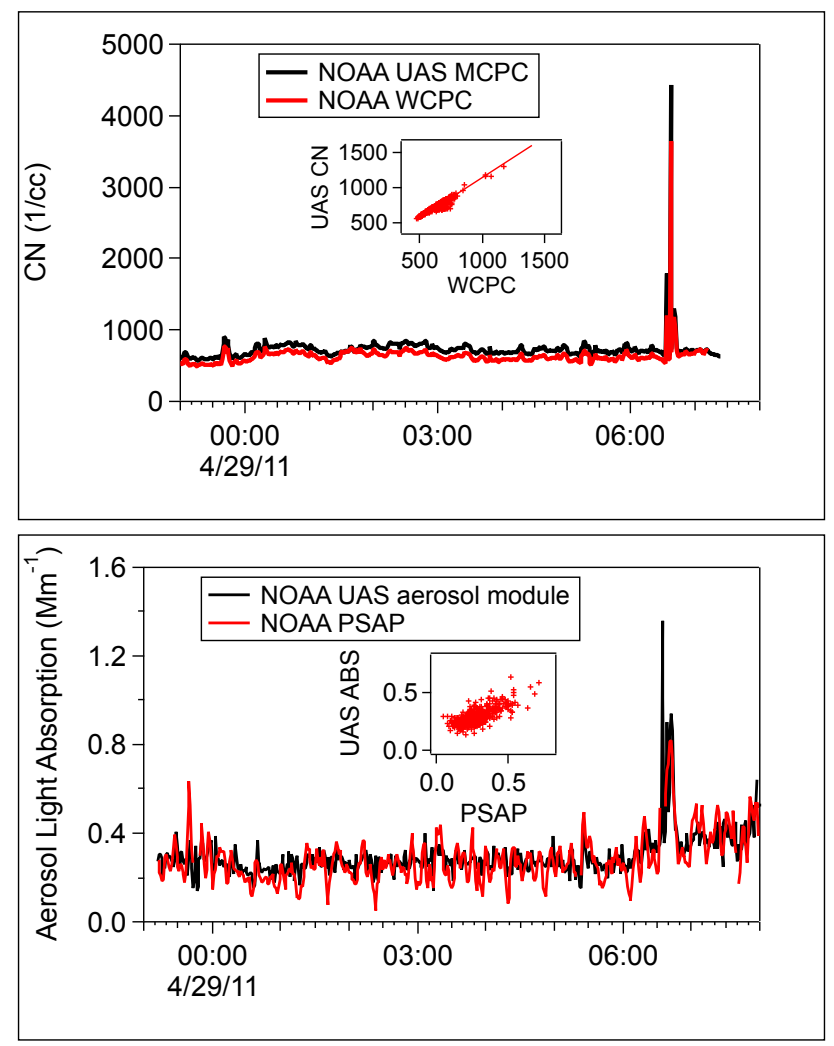

Fig. 3. Ground bases comparison at Gruvabadet Laboratory in $\mathrm{Ny}-$ Ålesund of the MANTA aerosol light absorption coefficient (ABS) and total particle measurements (MCPC) with the Radiance Research Particle Soot Absorption Photometer (PSAP) and a TSI water based $\mathrm{CN}$ counter (WCPC).

filter and a reference filter. The filter transmission, $\mathrm{Tr}$, is the ratio of the signals from the two filters. The light absorption coefficient is proportional to the rate of decrease of light transmittance divided by the flow rate of air through the filter (Bond et al., 1999). The temperature in the instrument payload was on average $20^{\circ} \mathrm{C}$ warmer than ambient which reduced the RH at the ABS filters to a very low level. The raw data were averaged into $60 \mathrm{~s}$ values for calculations of the rate of decrease of light transmittance. The minimum detectable level, MDL, defined as the peak-to-peak noise with the instrument running particle free air, was $0.2 \mathrm{Mm}^{-1}$. The error in the ABS measurement can be attributed to noise in the measured $\operatorname{Tr}$ value, instrument drift in the measured $\operatorname{Tr}$ value, uncertainty in the measured flow rate, and uncertainty in the measured filter spot area (Anderson et al., 1999). The data were not corrected for light scattering by particles that could bias the values by up to $10 \%$ (Bond et al., 1999). Data from the optical particle counter (not flown during STADS) would have provided a direct correction for light scattering. A quadrature sum of these errors yielded a relative uncertainty of $\pm 33 \%$ for an absorption coefficient of $1.0 \mathrm{Mm}^{-1}$. 


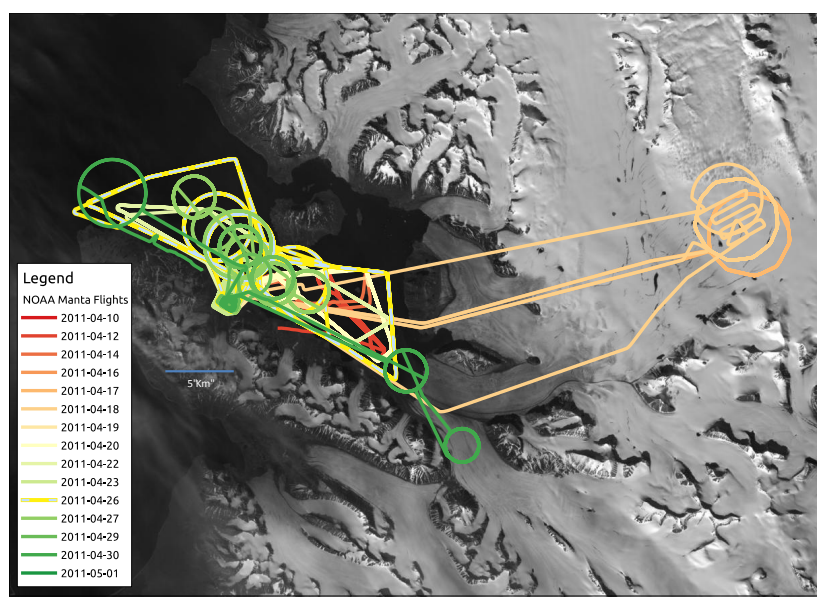

Fig. 4. The NOAA Manta flight tracks during the 2011 NOAASTADS/CICCI campaigns. A Landsat ETM+ mosaic from 1999 is used in the background. The flight with in which the aerosol layer was identified on 26 April is highlighted with yellow dash.

The Multi-Channel Chemical Sampler uses eight, off-theshelf filter holders (13 $\mathrm{mm}$ dia.) and a magnetically driven, rotary valve manifold to distribute the vacuum/flow from one central pump to each of the separate sampling channels. Remote serial commands are used to move the rotary valve to a new sampling channel at any desired time. The sampler fits in a cylindrical volume $7.6 \mathrm{~cm}$ in diameter by $5.1 \mathrm{~cm}$ long. The $2.5 \mathrm{~L} \mathrm{~min}^{-1}$ sample flow rate is measured by pressure drop through a laminar flow element (LFE) and the flow is actively controlled with an integrated pump. One of the 8 channels can be used to maintain flow through the device when no sample is desired. Filters may be extracted with water or other solvents for off-line chemical analysis by ionchromatography or other techniques.

The flow rates through all the instruments were reduced to standard temperature and pressure $\left(0^{\circ} \mathrm{C}, 1013.25 \mathrm{mb}\right)$. An integrated micro-controller system manages the control needs of each instrument and provides output data via a serial port at $1 \mathrm{~Hz}$. Data are stored on the aircraft computer.

\section{Results and discussion}

In addition to the UAS operations, aerosol measurements were made at the Gruvebadet Aerosol Laboratory located on the outskirts of Ny-Ålesund. The UAS aerosol measurement package was taken to the Gruvebadet Laboratory for a direct comparison with the ground-based measurements of total particle number measured with a TSI water-based condensation particle counter (WCPC) and aerosol light absorption coefficient measured with a Particle Soot Absorption Photometer (PSAP, Radiance Research). All of the instruments were configured to sample outside air from a common inlet mounted on the roof of the laboratory. The ground-based

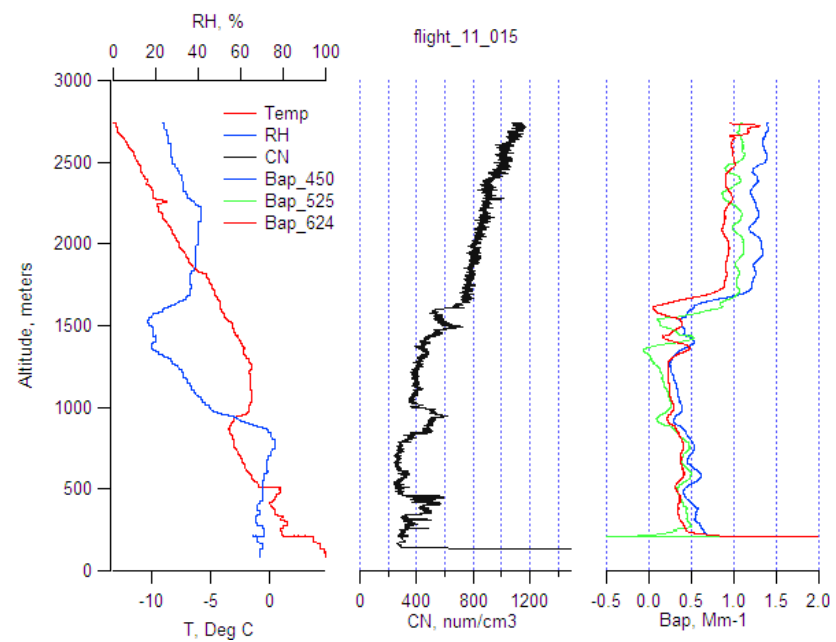

Fig. 5. The first $45 \mathrm{~min}$ of flight 15 (26 April 2011) showing the initial assent from the airport to $2700 \mathrm{~m}$ above the Kongsfjorden. Temperature and humidity (left), total particle number concentration $(\mathrm{CN})$ (middle), and aerosol light absorption coefficient at three wavelengths (right). The mean $\mathrm{CN}$ concentration and aerosol light absorption coefficient measured at the Gruvebadet Laboratory during the STADS were $400 \mathrm{~cm}^{-3}$ and $0.56 \mathrm{Mm}^{-1}$, respectively.

WCPC and UAS MCPC were well correlated with a slope of 1.14 and an $r^{2}=0.96$ (Fig. 3). The difference in the absolute concentration between the two instruments could be from the different fluids used to grow the particles. The signal from the ground-based aerosol light absorption measurement (PSAP) had more noise than the UAS ABS resulting in a less robust correlation $\left(r^{2}=0.56\right)$.

The majority of the research flights were flown over the Kongsfjorden (Fig. 4), immediately north of Ny-Ålesund. The typical flight plan was to ascend to $2700 \mathrm{~m}$, descend to the altitude of maximum aerosol concentration, and then to sample at that altitude for the remainder of the flight (typically 1 to $2 \mathrm{~h}$ ). Vertical profiles of aerosol and meteorological parameters from the initial assent from the airport to $2700 \mathrm{~m}$ over Kongsfjorden on 26 April (flight 15) are shown in Fig. 5. The boundary layer extended up to $\approx 1000 \mathrm{~m}$ and was capped by a small temperature inversion. The lower layer was moist with an RH between 70 and $80 \%$. The RH dropped above the boundary layer to $15 \%$ at $1500 \mathrm{~m}$ and then increased to $40 \%$ at $2200 \mathrm{~m}$. There was a small increase in total particle number just below the top of the boundary layer but no increase in the aerosol light absorption coefficient from these particles. The upper layer $(>1700 \mathrm{~m})$ had the highest particle number concentrations and the highest aerosol light absorption coefficients.

Layers of higher aerosol light absorption aloft have been reported previously (de Villiers et al., 2010; Spackman et al., 2010; Brock et al., 2011) and are generally thought to be the result of meridional transport of pollution-laden air masses from the mid-latitudes to the Arctic (e.g., Shaw, 1995; 
Sensitivity at Footprint m.a.s.l.: AIRTRACER

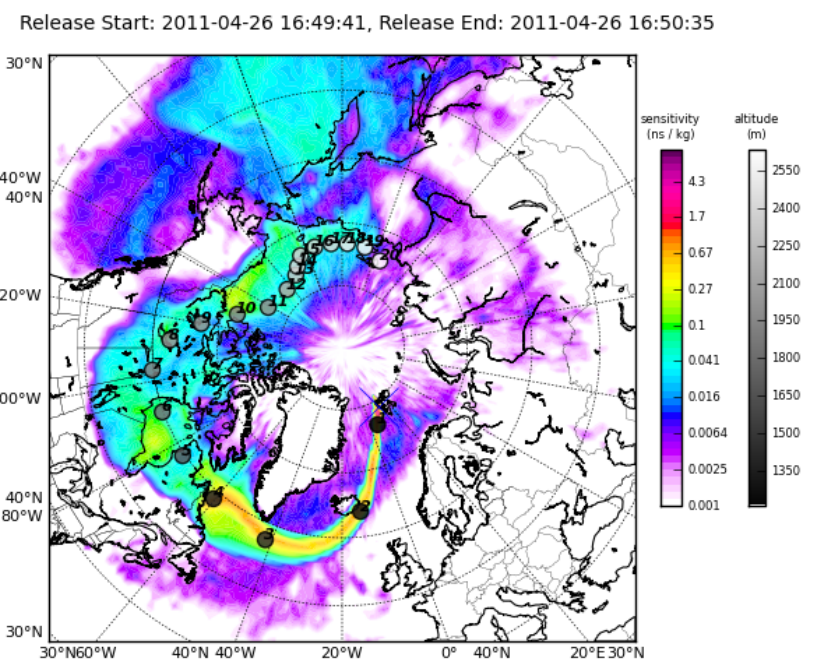

Fig. 6. FLEXPART sensitivity showing the most probable origin of the airmass sampled in Svalbard on 26 April. The gray circles show the daily location going back 20 days prior to 26 August. The shade of gray indicates the altitude of the airmass.

Quinn et al., 2007). The dominant sources include fossil fuel and biofuel combustion in northern Europe and Asia (Stohl, 2006). The impact of this filamentary transport phenomenon is poorly known. A better understanding of sources and the components of these layers is critical to calculating the warming aloft and deposition to the snow/ice surface. These layers are often well above the Zepplin mountain top observatory and thus can only be sampled by aircraft or balloons. The UAS is ideally suited for making regular measurements of these layers.

One filter sample was collected on each flight for ion analysis. Sulfate concentrations (the most abundant ion) ranged from below detection limit $\left(0.04 \mu \mathrm{g} \mathrm{m}^{-3}\right.$ for a $100 \mathrm{~min}$ sample at $2.5 \mathrm{~L} \mathrm{~min}^{-1}$ ) to $0.51 \mu \mathrm{g} \mathrm{m}^{-3}$. Daily average surface sulfate concentrations measured at Gruvebadet Laboratory during STADS ranged from $0.45-0.87 \mu \mathrm{g} \mathrm{m}^{-3}$. The single filter sample of ion concentrations was not useful in assessing aerosol sources. Future flights should explore a more sensitive technique that would include trace metal concentrations (e.g., SEM/XRF). For example, the ratio of non-crustal (nc) manganese $(\mathrm{Mn})$ to $\mathrm{nc}$ vanadium $(\mathrm{V})$ has been shown to be a useful tracer of regional sources (Rahn, 1981). Recently, Hegg et al. (2010) used tracer species and positive matrix factorization (PMF) to differentiate four different sources of BC and non-BC light absorbing aerosols to the Arctic. Vanillin and levoglucosan were used to identify and separate agricultural and biomass burning.

FLEXPART, a Lagrangian particle dispersion model (Stohl et al., 2005), was used to investigate the origin of aerosols sampled by the MANTA (Fig. 6). The weather pattern on 26 April showed a cyclonic flow circulating around the Arctic. Approximately $80 \%$ of the 20 day emission sensitivity (trajectory) was over water, passing first over Iceland, then northern Canada and finally back to northern Russia. The absorbing particles measured aloft in Ny-Ålesund were most likely aged Arctic Haze, but without chemical tracers it is difficult to assign a source to the particles.

\section{Conclusions}

UAS can provide high quality vertical distributions of aerosol properties that can be used to better understand the transport and distributions of $\mathrm{BC}$ in the Arctic. The measurements during STADS showed that the transport to Ny-Ålesund occurred above the boundary layer and hence were not sampled by ground or mountain stations. Regular UAS measurements in the Arctic could provide the vertical aerosol data needed to test climate models and satellite retrievals.

Data from the experiment are available at http://saga.pmel. noaa.gov/Field/CICCI/index.html.

Acknowledgements. This work was supported by the NOAA UAS and Arctic Programs. Brechtel Mfg. Inc. acknowledges support for the development of the ACCESS UAS instrument suite under NOAA SBIR Contract DG133R-07-CN-0193. Partial funding for JFB was provided through the Norwegian Research Council project VAUUAV (NFR \#184724) and the U.S. NSF iisPACS project (\#ARC-1023651). This is PMEL contribution number 3979. The authors thank Rune Storvold and the NORUT UAS team for guidance and support in Svalbard, Mauro Mazzola for assistance at the Gruvebadet Laboratory, and Dirk Tagawa, Nick Delich, Rafael Gayton, Drew Hamilton, Derek Coffman, Kristen Schulz for their technical assistance. Coordination and management of field activities in Svalbard were funded through the RISCC project (NFR \#196204).

Edited by: M. Sipilä

\section{References}

Anderson, T. L., Covert, D. S., Wheeler, J. D., Harris, J. M., Perry, K. D., Trost, B. E., Jaffe, D. J., and Ogren, J. A.: Aerosol backscatter fraction and single scattering albedo: Measured values and uncertainties at a coastal station in the Pacific Northwest, J. Geophys. Res., 104, 26793-26807, 1999.

Bond, T. C., Anderson, T. L., and Campbell, D.: Calibration and intercomparison of filter-based measurements of visible light absorption by aerosols, Aerosol Sci. Technol., 30, 582-600, 1999.

Brock, C. A., Cozic, J., Bahreini, R., Froyd, K. D., Middlebrook, A. M., McComiskey, A., Brioude, J., Cooper, O. R., Stohl, A., Aikin, K. C., de Gouw, J. A., Fahey, D. W., Ferrare, R. A., Gao, R.-S., Gore, W., Holloway, J. S., Hübler, G., Jefferson, A., Lack, D. A., Lance, S., Moore, R. H., Murphy, D. M., Nenes, A., Novelli, P. C., Nowak, J. B., Ogren, J. A., Peischl, J., Pierce, R. B., Pilewskie, P., Quinn, P. K., Ryerson, T. B., Schmidt, K. S., Schwarz, J. P., Sodemann, H., Spackman, J. R., Stark, H., Thomson, D. S., Thornberry, T., Veres, P., Watts, L. A., Warneke, 
C., and Wollny, A. G.: Characteristics, sources, and transport of aerosols measured in spring 2008 during the aerosol, radiation, and cloud processes affecting Arctic Climate (ARCPAC) Project, Atmos. Chem. Phys., 11, 2423-2453, doi:10.5194/acp-11-24232011, 2011.

de Villiers, R. A., Ancellet, G., Pelon, J., Quennehen, B., Schwarzenboeck, A., Gayet, J. F., and Law, K. S.: Airborne measurements of aerosol optical properties related to early spring transport of mid-latitude sources into the Arctic, Atmos. Chem. Phys., 10, 5011-5030, doi:10.5194/acp-10-5011-2010, 2010.

Doherty, S. J., Warren, S. G., Grenfell, T. C., Clarke, A. D., and Brandt, R. E.: Light-absorbing impurities in Arctic snow, Atmos. Chem. Phys., 10, 11647-11680, doi:10.5194/acp-1011647-2010, 2010.

Flanner, M. G.: Integrating anthropogenic heat flux with global climate models, Geophys. Res. Lett., 36, L02801, doi:1029/2008GL036465, 2009.

Flanner, M. G., Zender, C. S., Randerson, J. T., and Rasch, P. J.: Present day climate forcing and response from black carbon in snow, J. Geophys. Res., 112, D11202, doi:10.1029/2006JD008003, 2007.

Flanner, M. G., Zender, C. S., Hess, P. G., Mahowald, N. M., Painter, T. H., Ramanathan, V., and Rasch, P. J.: Springtime warming and reduced snow cover from carbonaceous particles, Atmos. Chem. Phys., 9, 2481-2497, doi:10.5194/acp-9-24812009, 2009.

Hansen, J. and Nazarenko, L.: Soot climate forcing via snow and ice albedos, P. Natl. Acad. Sci. USA, 101, 423-428, 2004.

Hansen, J., Sato, M., Ruedy, R., Nazarenko, L., Lacis, A., Schmidt, G. A., Russell, G., Aleinov, I., Bauer, M., Bauer, S., Bell, N., Cairns, B., Canuto, V., Chandler, M., Cheng, Y., Del Genio, A., Faluvegi, G., Fleming, E., Friend, A., Hall, T., Jackman, C., Kelley, M., Kiang, N., Koch, D., Lean, J., Lerner, J., Lo, K., Menon, S., Miller, R., Minnis, P., Novakov, T., Oinas, V., Perlwitz, Ja., Perlwitz, Ju., Rind, D., Romanou, A., Shindell, D., Stone, P., Sun, S., Tausnev, N., Thresher, D., Wielicki, B., Wong, T., Yao, M., and Zhang, S.: Efficacy of climate forcings, J. Geophys. Res., 110, D18104, doi:10.1029/2005JD005776, 2005.

Hegg, D. A., Warren, S. G., Grenfell, T. C., Doherty, S. J., and Clarke, A. D.: Sources of light-absorbing aerosol in arctic snow and their seasonal variation, Atmos. Chem. Phys., 10, 1092310938, doi:10.5194/acp-10-10923-2010, 2010.

Hirdman, D., Burkhart, J. F., Sodemann, H., Eckhardt, S., Jefferson, A., Quinn, P. K., Sharma, S., Ström, J., and Stohl, A.: Longterm trends of black carbon and sulphate aerosol in the Arctic: changes in atmospheric transport and source region emissions, Atmos. Chem. Phys., 10, 9351-9368, doi:10.5194/acp-10-93512010, 2010.

Jacobson, M. Z.: Short-term effects of controlling fossil-fuel soot, biofuel soot and gases, and methane on climate, arctic ice, and air pollution health, J. Geophys. Res., 115, D14209, doi:10.1029/2009JD013795, 2010.

Køltzow, M.: The effect of a new snow and ice albedo scheme on regional climate model simulation, J. Geophys. Res., 112, D07110, doi:10.1029/2006JD007693, 2007.

Law, K. S. and Stohl, A.: Arctic air pollution: Origins and impacts, Science, 315, 1537-1540, doi:10.1126/science.1137695, 2007.
McConnell, J. R., Edwards, R., Kok, G. L., Flanner, M. G., Zender, C. S., Saltzman, E. S., Banta, J. R., Pasteris, D. R., Carter, M. M., and Kahl, J. D. W.: 20th century industrial black carbon emissions altered Arctic climate forcing, Science, 317, 1381-1384, 2007.

Quinn, P. K., Shaw, G., Andrews, E., Dutton, E. G., Ruoho-Airola, T., and Gong, S. L.: Arctic Haze: Current Trends and Knowledge Gaps, Tellus B, 59, 99-114, 2007.

Quinn, P. K., Bates, T. S., Baum, E., Doubleday, N., Fiore, A. M., Flanner, M., Fridlind, A., Garrett, T. J., Koch, D., Menon, S., Shindell, D., Stohl, A., and Warren, S. G.: Short-lived pollutants in the Arctic: their climate impact and possible mitigation strategies, Atmos. Chem. Phys., 8, 1723-1735, doi:10.5194/acp8-1723-2008, 2008.

Rahn, K. A.: The Mn/V ratio as a tracer of large-scale sources of pollution aerosol for the Arctic, Atmos. Environ., 15, 1457-1464, 1981.

Sharma, S., Andrews, E., Barrie, L., Ogren, J., and Lavoue, D.: Variations and sources of the equivalent black carbon in the high Arctic revealed by long-term observations at Alert and Barrow: 1989-2003, J. Geophys. Res., 111, D14208, doi:10.1029/2005JD006581, 2006.

Shaw, G.: The Arctic haze phenomenon, B. Am. Meteorol. Soc., 76, 2403-2413, 1995.

Shindell, D.: Local and remote contributions to Arctic warming, Geophys. Res. Lett., 34, L14704, doi:10.1029/2007GL030221, 2007.

Shindell, D. and Faluvegi, G.: Climate response to regional radiative forcing during the twentieth century, Nat. Geosci., 2, 294-300, doi:10.1038/NGEO473, 2009.

Shindell, D. T., Chin, M., Dentener, F., Doherty, R. M., Faluvegi, G., Fiore, A. M., Hess, P., Koch, D. M., MacKenzie, I. A., Sanderson, M. G., Schultz, M. G., Schulz, M., Stevenson, D. S., Teich, H., Textor, C., Wild, O., Bergmann, D. J., Bey, I., Bian, H., Cuvelier, C., Duncan, B. N., Folberth, G., Horowitz, L. W., Jonson, J., Kaminski, J. W., Marmer, E., Park, R., Pringle, K. J., Schroeder, S., Szopa, S., Takemura, T., Zeng, G., Keating, T. J., and Zuber, A.: A multi-model assessment of pollution transport to the Arctic, Atmos. Chem. Phys., 8, 5353-5372, doi:10.5194/acp-85353-2008, 2008.

Spackman, J. R., Gao, R. S., Neff, W. D., Schwarz, J. P., Watts, L. A., Fahey, D. W., Holloway, J. S., Ryerson, T. B., Peischl, J., and Brock, C. A.: Aircraft observations of enhancement and depletion of black carbon mass in the springtime Arctic, Atmos. Chem. Phys., 10, 9667-9680, doi:10.5194/acp-10-9667-2010, 2010.

Stohl, A.: Characteristics of atmospheric transport into the arctic troposphere, J. Geophys. Res., 111, D11306, doi:10.1029/2005JD006888, 2006.

Stohl, A., Forster, C., Frank, A., Seibert, P., and Wotawa, G.: Technical note: The Lagrangian particle dispersion model FLEXPART version 6.2, Atmos. Chem. Phys., 5, 2461-2474, doi:10.5194/acp-5-2461-2005, 2005.

UNEP: Integrated assessment of black carbon and tropospheric ozone: summary of decision makers, UNEP/GC/26/INF/20, 2011. 